\title{
Çocuk İstismarı Potansiyelini Yordayan Faktörlerin İncelenmesi
}

\author{
An Examination of the Factors that Predict Potential Child Abuse
}

\begin{abstract}
Gökçe CAN* Utku BEYAZIT ${ }^{* *}$

$\ddot{O}_{z:}$ Çocuk istismarı konusu günümüzde araştırmacıların ilgisini çekmekte ve bu konuya ilişkin yapılan çalışmaların sayısı gün geçtikçe artmaktadır. Çocuk istismarına neden olabilecek risk faktörlerinin incelenmesine yönelik olarak, sosyo-ekonomik faktörlerle birlikte, ebeveynlerin çocukluk dönemi yaşantılarının ve kişilik özelliklerinin çocuklarına yönelik istismar potansiyelleri açısından ele alınması önem taşımaktadır. Bu noktadan hareketle bu çalışmada, ebeveynlerin çocuk istismarı potansiyelini yordayan faktörlerin incelenmesi amaçlanmıştır. Çalışmaya Kuzey Kıbrıs'ta yaşayan 214 ebeveyn dahil edilmiştir. Veri toplama aracı olarak araştırmacı tarafından literatürden faydalanılarak hazırlanan "Sosyodemografik Bilgi Formu", "Milner Çocuk İstismarı Potansiyel Envanteri (ÇïPE)", "Çocukluk Çağı Travmaları Ölceği (ÇÇTÖ)" ve "Hacettepe Kişilik Envanteri (HKE) kullanılmıştır. Araştırmanın katılımcılarının belirlenmesinde "Uygun Örnekleme" yöntemi kullanılmıştır. Araştırma bulgularına göre, ebeveynlerin cinsiyet, öğrenim durumu, evin mülkiyeti, çocukluk çağı travmaları ve kişilik özelliklerinin çocuklarına yönelik istismar potansiyelini istatistiksel açıdan anlamlı düzeyde $(\mathrm{p}<0.05)$ yordayan faktörler olduğu tespit edilmiştir. İstismara yol açan etmenlerin değerlendirilmesinin, çocuk istismarının önlenmesine yönelik önleyici çalışmaların planlanabilmesi ve uygulanabilmesi açısından önem taşıdığı düşünülmektedir. Araştırma sonucunda elde edilen bulgular doğrultusunda çocuk istismarı konusunda çalışan uzmanlara, kurum ve kuruluşlara önerilerde bulunulmuştur.
\end{abstract}

Anahtar sözcükler: Çocuk, Çocuk İstismarı Potansiyeli, Çocukluk Çağı Travması, Kişilik Özellikleri

Abstract: The subject of child abuse attracts the attention of researchers and the number of studies conducted on this subject has recently increased. The examination of parents' childhood experiences and personality characteristics is crucial in terms of determining the risk factors that lead to child abuse. Therefore, within this context, the aim was to examine those factors that predict the child abuse potential of parents. The study group comprised 214 parents living in North Cyprus. This study employed the "Sociodemographic Information Form," the "Childhood Trauma Questionnaire," the "Milner Child Abuse Potential Inventory," and the "Hacettepe Personality Inventory." Participants were found through employing the convenience sampling method. The data obtained was evaluated with the SPSS 21.0 program. According to the results, the parents' sex, educational level, sexual abuse, self-actualization, social relations and antisocial tendency variables were found to be factors predictive of child abuse potential $(p<0.05)$. It is thought that the assessment of the risk factors which lead to child abuse is crucial in terms of planning and implementing programs for the prevention of child abuse. As a result of this research, suggestions have been made to experts, institutions and organizations working on the problem of child abuse.

Keywords: Child, Child Abuse Potential, Childhood Trauma, Personality Traits

* Bilim Uzm., Sı ğınmacılar ve Göçmenlerle Dayanışma Derneği, Gaziantep. gokcecan23@gmail.com.tr

** Dr. Öğr. Ü., Akdeniz Üniversitesi, Kumluca Sağllk Bilimleri Fakültesi, Çocuk Gelişimi Bölümü, Antalya. utkubeyazit@akdeniz.edu.tr 


\section{Giriş}

Dünya Sağlık Örgütü çocuk istismarını, 18 yaşından küçük bir bireyin fiziksel, duygusal ve sosyal gelişimini etkileyen ve çocuğa zarar veren her türlü davranış olarak tanımlamaktadır (Dünya Sağlık Örgütü 2014). Şahin (2014) ise çocuk istismarını, çocukların başta ebeveynleri olmak üzere, kendilerine bakmakla yükümlü kimseler veya diğer yetişkinler tarafından; fiziksel, zihinsel, duygusal ve cinsel gelişimlerini engelleyen, ruh veya beden sağlığına zarar veren durumlarla karşı karşıya bırakılması şeklinde tanımlamaktadır. Bu tanımlamalara dayalı olarak çocuk istismarı, zarar verici davranışın türüne göre, duygusal istismar, cinsel istismar, fiziksel istismar ve ihmal olmak üzere dört grupta incelenmektedir (Polat 2007). Çoğunlukla travmaya neden olan çocuk istismarının, diğer çocukluk çağı travmaları içinde, çocuğa genellikle en yakınları tarafından yapılıyor olması nedeniyle, tanımlanması ve tedavi edilmesi zor bir travma şekli olduğu belirtilmektedir (Can 2009). Çocuk istismarının, karmaşık ve tespit edilmesi güç nedenlere dayalı olarak ortaya çıktığı, ağır sonuçların yaşanmasına, bireyin yaşam kalitesinin ve yaşam doyumunun olumsuz yönde etkilenmesine neden olan ciddi bir sosyal problem olduğuna dikkat çekilmektedir (Şahin 2009; Beyazova 2014).

UNICEF verilerine göre, tüm dünyada her y1l beş yüz milyon ile bir buçuk milyar arasında çocuk şiddete maruz kalmaktadır (UNICEF, 2014). Sosyal Hizmetler ve Çocuk Esirgeme Kurumu (2010) tarafından yapılan Çocuk İstismarı ve Aile İçi Şiddet araştırmasına göre ise, Türkiye'de yaşayan ve yaşları 7-18 arasında değişen çocukların \%51'i duygusal istismara, \%45'i fiziksel istismara ve \%25'i ihmale maruz kalmaktadır. Kuzey Kıbrıs'ta 2003 yılında yapılan araştırmanın sonuçlarına göre ise, öğrencilerden \%38.9'unun hayatı boyunca en az bir kez tokat yedikleri, \%4'ünün sık sık tokat atılarak cezalandırıldıkları, \%13.3'ünün en az bir kez anne ve babası tarafindan yumruk veya tekme atılarak cezalandırıldıkları, \%10.1'inin sopa, kemer gibi bir cisimle dövüldükleri, \%5.4'ünün yakıldıkları, \%8.4'ünün ise kilitlenerek veya hapsedilerek cezalandırıldıkları tespit edilmiştir (Çakıcı, 2003).

Çocuk istismarına ilişkin risk faktörleri incelendiğinde, alan yazında konuya ilişkin çeşitli ortak bulguların ortaya konduğu görülmektedir. Çocuğun cinsiyeti (Kara 2004; Soylu et al. 2013; Douglas 2014); erken doğmuş olması, düşük kilolu olması (Kezer 2014); düşük sosyoekonomik düzey (Azizoğlu 2009; Karakoç 2009), çocuk sayısının fazla olması (Sebre ve ark., 2004; Tuna, 2010), sağlıksız yaşam koşulları (İşmen 2004; Beyazova 2014), erken yaşta çocuk sahibi olma (Köse et al. 2003; Küpeli et al. 2003); anne babanın çocukluk döneminde istismara maruz kalmış olmaları (Bilge 2009; Tyler et al. 2006; Bilge et al. 2013; Ayaz et al. 2013; Dallar-Bilge et al. 2013) çocuk istismarına neden olabilen risk faktörleri arasındadır. Kendi anne babaları tarafindan sağlıklı bir ebeveyn tutumu ile yetişmemiş çocukların benzer tutumları yetişkinlik döneminde kendi çocuklarına yönelik olarak sürdürebildikleri ve bu durumun çocuğa yönelik istismar riskini artırabildiği belirtilmektedir (Yavuzer 2003). Bu etmenlerin yanı sıra, ebeveynlerin psikolojik özelliklerinin de çocuğa yönelik istismar riskini önemli ölçüde etkilediği; ebeveynlerin öfkelerini kontrol edememesi, yalnızlık hissetmesi, mutsuz ve stresli olması (Pekdoğan 2016) ve çeşitli ruhsal sorunlarının olmasının (Stewart et al. 2006; Çengel-Kültür et al. 2007; Tüzer \& Akdă̆ 2010) çocuklarını istismar etme riskini artırdığı belirtilmektedir.

Çocuğa uygulanan şiddetin boyutuna göre çocuğun vücudunun farklı bölümlerinde farklı boyutlarda yaralar, morluklar, kesiler, kanamalar, kırıklar, yanıklar, göz ve beyin hasarları, iç organ zedelenmeleri ve bütün bunların sonucunda meydana gelen çeşitli hastalıklar, kalıcı sakatlanmalar gibi fiziksel sonuçlarının yanı sıra çocuğun kişilik özelliklerinin de olaya bağlı olarak olumsuz etkilenebileceği ileri sürülmektedir (Altıparmak 2008). İstismar sirasında uygulanan zorlama veya şiddet seviyesinin artmasının, yaşanan çaresizlik duygusunu derinleş- 
tirdiği; bu durumun ise, yaşanan ruhsal travmanın artırdığı belirtilmektedir (Demir 2008). İstismarın klinik özeliklerinin ve çocuk üzerindeki etkilerinin; istismarın şekline, süresine, fiziksel zararın varlığına, çocuğun yaşına ve gelişim basamağına, çocuğun istismarcı ile olan ilişkisine, ruhsal özelliklerine ve travma öncesi psikolojik gelişimine bağlı olarak değiştiği ileri sürülmektedir (Aktepe 2009).

İstismara maruz kalan çocuklarda bağımlı kişilik geliştirme, değersizlik duyguları geliştirme, uyumsuz ve saldırgan davranışlarda bulunma gibi özelliklerin ortaya çıkabileceği; kendilerini yaşadıkları travmadan korumak için tüm enerjilerini harcadıklarında gelişimlerinin bozulduğu veya geciktiği (Polat 2007); depresyon, anksiyete ve travma sonrası stres bozukluğu gibi ruhsal sorunlar yaşayabildikleri belirtilmektedir (Siyez 2003; Öztep 2010). Bütün bunların yanı sıra çocukluk döneminde yaşanılan istismarın, yetişkinlik döneminde kişilik özelliklerine yansımalarının olduğu; çocukluğunda herhangi bir istismara maruz kalan bireylerin yetişkinlikte kendine güvenmeme, kendi becerilerinin farkında olmama, tek başına kararlar verememe, reddedildiği ve bir işe yaramadığı duygusu içinde olma gibi özellikler taşıdıkları (Allen \& Lauterbauch 2007), çeşitli zihinsel rahatsızlıklar ve uyum sorunları yaşadıkları ifade edilmektedir (Tackett 2009). Bu nedenle çocukluk dönemlerinde istismara maruz kalan kişilerin başkalarına empati duyamayan, çevrelerine karşı duyarsız ve kolay incinebilen kişiler haline geldikleri (Şahin 2009); fiziksel ve duygusal olarak kötü muamele tutumlarını normalleştirdikleri ve bu tutumları uygun disiplin biçimleri olarak kabul etme eğilimine sahip olmalarının da çocuklarına yönelik istismar riskini artırdığı ifade edilmektedir (Bower-Russa, et al. 2001).

Çocuk istismarı konusu günümüzde araştırmacıların ilgisini çekmekte ve bu konuya ilişkin yapılan çalışmaların sayısı gün geçtikçe artmaktadır. Ancak çocuk istismarı sorununa yönelik önleyici çalışmaların planlanabilmesi ve uygulanabilmesi açısından konunun bir bütün olarak ele alınması, istismara yol açan etmenlerin değerlendirilmesi önem taşımaktadır. Alan yazın incelendiğinde, sosyo ekonomik etmenlerin çocuğa yönelik istismar riskini önemli ölçüde artırabileceğine ilişkin bulgular dikkat çekmektedir. Bununla birlikte, olumsuz yaşam koşullarının ve düşük sosyo-ekonomik düzeyin çocuğa yönelik istismar riskine her durumda yol açmayabileceği; risk etmenleri değerlendirilirken, sosyo-ekonomik faktörlerle birlikte, ebeveynlerin çocukluk dönemi yaşantılarının ve kişilik özelliklerinin çocuklarına yönelik istismar potansiyelleri açısından ele alınması gerektiği düşünülmektedir. Bu noktadan hareketle bu çalışmada, ebeveynlerin çocuk istismarı potansiyelini yordayan faktörlerin incelenmesi ve yorumlanması amaçlanmıştır.

\section{Yöntem}

\section{Araştırma Modeli}

$\mathrm{Bu}$ çalışma, Kuzey Kıbrıs'ta yaşayan ebeveynlerin çocuk istismarı potansiyellerini yordayan faktörlerin incelenmesi amacıyla yapılmış tanımlayıcı bir çalışmadır.

\section{Örneklem}

Örneklem metodu olarak, "Uygun Örnekleme Metodu” kullanılmıştır. Bu yöntem para, zaman ve işgücü açısından araştırmacılara kolaylıklar tanıması nedeniyle kullanılmıştır (Gravetter \& Forzano 2012). Veri toplama araçları gönüllü olan katılımcılara uygulanmıştır. Araştırmada veriler dağıt-topla yöntemi ile elde edilmiştir. Uygulama öncesinde araştırmacı, ebeveynlere kendisini tanıtarak araştırmanın amacı ve veri toplama araçlarının nasıl yanıtlanacağı konularında gerekli açıklamaları yapmış ve ebeveynlerin uygulama ile ilgili sorularını yanıtlamıştır. Sözlü bilgilendirmenin dışında katılımcılara "Bilgilendirme Formu" da verilmiştir. Araştırmaya 
katılımlarına ilişkin onamları alınmıştır. Bu kapsamda Kuzey Kıbrıs'ta yaşayan 18 yaşından küçük bir çocuğu olan veya 18 yaşından küçük bir çocuğa bakmakla yükümlü olan yaklaşık 450 ebeveyne anket formları kapalı zarflar içinde teslim edilip, aynı şekilde kapalı zarflar içinde teslim alınmıştır. Dağıtılan formlardan 224 tanesi geri dönmüştür. Çok sayıda maddenin boş bırakılması nedeniyle 10 katılımcıya ait form değerlendirmeye alınmamış ve sonuç olarak araştırmaya 214 ebeveyn dahil edilmiştir. Araştırmada yer alan ebeveynlerin \%66.82'si (n=143) kadın, \%33.18'i ( $\mathrm{n}=71)$ erkektir. Yaş gruplarına bakıldığında ebeveynlerin \%20.09'nun $(\mathrm{n}=43)$ 30 yaş ve altı, \%51.40'ının ( $\mathrm{n}=110)$ 31-40 yaş arası ve \%28.50'sinin $(\mathrm{n}=61) 41$ yaş ve üzeri yaş grubunda yer aldığı tespit edilmiştir.

\section{Veri Toplama Araçları}

Veri toplama aracı olarak literatürden faydalanılarak araştırmacı tarafindan hazırlanan "Sosyodemografik Bilgi Formu", "Milner Çocuk İstismarı Potansiyel Envanteri (ÇiPE)", "Çocukluk Çă̆ı Travmaları Ölçeği (ÇÇTÖ)" ve "Hacettepe Kişilik Envanteri (HKE)" baz alınarak uygulanmıştır.

\section{Sosyo-Demografik Bilgi Formu}

"Sosyo-Demografik Bilgi Formunun" içinde yer alan değişkenler, çocuk istismarı ve ihmali ile ilgili literatür gözden geçirilerek ve çocuk istismarı ile ilişkili kavramlar da göz önünde bulundurularak araştırmacı tarafindan hazırlanmıştır. Formda ebeveynlerin cinsiyet, yaş, doğum yeri, medeni durumu, öğrenim durumu, çalışma durumu, çocuk sayısı, oturdukları evin mülkiyeti ve gelir düzeyine ilişkin sorulara yer verilmiştir.

\section{Çocukluk Çağı Travmaları Ölçeği (ÇÇTÖ)}

Çocukluk Çağı Travmaları Ölçeği Bernstein ve ark. tarafından 1994 yılında 20 yaş öncesi istismar ve ihmal yaşantılarını geriye dönük ve niceliksel olarak değerlendirmek amacı ile geliştirilmiştir. Ölçek 28 maddeden oluşan beşli likert tipi bir öz bildirim ölçeğidir. Ölçeğin fiziksel istismar alt ölçeği, duygusal istismar alt ölçeği, cinsel istismar alt ölçeği, duygusal ihmal alt ölçeği, fiziksel ihmal alt ölçeği olmak üzere beş alt boyutu bulunmaktadır. Ölçeğe ait toplam puan en düşük 54, en yüksek ise 270 puandır. Sorular 1 ile 5 puan arasında puanlanmaktadır. Yanıtlar (1) hiçbir zaman, (2) nadiren, (3) zaman zaman, (4) sıklıkla, (5) çok sık olarak verilmektedir. Ölçeğin Cronbach alfa değerleri 0.79-0.94 arasında değişmektedir. Ölçek Türkçeye 1996 yılında Vedat Şar tarafından uyarlanmıştır (Şar et al. 2012). Ölçeğin Türkçe versiyonunun iç tutarlıl1ğını gösteren Cronbach alfa değeri 0.93 olarak bulunmuştur (Aydemir \& Köroğlu 2006). Bu araştırma kapsamında yapılan iç tutarlılık testi sonucunda ise ölçek geneline ilişkin Cronbach alfa değeri 0.77 bulunmuştur.

\section{Milner Çocuk İstismarı Potansiyeli Envanteri (ÇİPE)}

Joel Milner tarafından 1976 yılında yetişkinlerin çocuklara yönelik istismar potansiyellerini belirlemek amacı ile geliştirilmiştir. Ölçek 160 sorudan oluşmaktadır. Ölçekte, istismar, katılık, mutsuzluk, çocuk ve kendisiyle ilgili sorunlar, aile ile ilgili sorunlar, başkaları ile ilgili sorunlar ve iki geçerlilik ölçeği olmak üzere on alt ölçek bulunmaktadır (Milner 1986). Araştırma kapsamında, 77 maddeden oluşan ve "katıllyorum-katılmıyorum" şeklinde yanıtlanan istismar alt ölçeği kullanılmıştır. Envanter sorularına verilen cevaplara ait puanların hesaplanması, envanterin ekinde yer alan bir puanlama çizelgesine göre yapılmaktadır. Örneğin; beşinci soruya verilen "katıllyorum" cevabının puanı 14 puan iken; üçüncü soruya verilen "katılmıyorum" cevabının puanı 1 puan olarak hesaplanmaktadır. İstismar alt ölçeğinden alınabilecek en yüksek puan 486'dır. Alınan yüksek puanlar çocuk istismarı potansiyelinin yüksek olduğunu göstermektedir. 
ÇİPE'nin konverjan geçerlik çalışmasında çocuk istismarı potansiyelinin, özellikle stres $(\mathrm{r}=0.71, \mathrm{p}<0.05)$ ve depresyonla $(\mathrm{r}=0.71, \mathrm{p}<0.05)$ ilişkili olduğu tespit edilmiştir (Milner et al. 1988). Kutsal tarafindan 2004 yılında gerçekleştirilen "Milner Çocuk İstismarı Potansiyeli Ölçeğinin Türkiye Geçerliliği" çalışmasında ise istismar alt ölçeğinin Cronbach Alpha katsayısı ise 0.94 olarak hesaplanmıştır (Kutsal 2004). Bu araştırma kapsamında yapılan iç tutarlılık testi sonucunda ölçek geneline ilişkin olarak Cronbach alfa değeri 0.90 olarak bulunmuştur.

\section{Hacettepe Kişilik Envanteri (HKE)}

Hacettepe Kişilik Envanteri, Özgüven ve arkadaşları tarafından 1976 yılında bireyin sosyal uyum ve kişisel uyum düzeyini ölçmek amaciyla geliştirilmiştir. Envanterde, "evet-hayır" şeklinde yanıtlanan, 168 madde bulunmaktadır. Envanter, Kişisel Uyum ve Sosyal Uyum olmak üzere iki alt boyuttan oluşmaktadır. Kişisel uyum alt ölçeği kendini gerçekleştirme, duygusal kararlılık, nevrotik eğilimler ve psikotik belirtiler olmak üzere dört alt boyuttan; sosyal uyum alt ölçeği ise aile ilişkileri, sosyal ilişkiler, sosyal normlar ve antisosyal ilişkiler olmak üzere sekiz alt boyuttan oluşmaktadır. Envanterin puanlanması bir cevap anahtarına göre yapılmaktadır, anahtarda belirtilen her bir maddeye 1 puan verilmektedir. HKE alt ölçeklerinin her birinden alınabilecek maksimum puan 20'dir. Kişisel ve Sosyal Uyum puanlarının alabileceği en yüksek değer 80 ve Genel Uyum puanının alabileceği en yüksek değer ise 160'tır. Puanın yüksekliği olumsuz, düşüklüğü ise olumlu yönde uyumu ifade etmektedir. (Özgüven 1992). Hacettepe Kişilik Envanterinin güvenirliğini belirlemek amacıyla yapılan çalışmada Cronbach Alpha katsayısı 0.84 olarak hesaplanmıştır. Bu araştırma kapsamında yapılan iç tutarlılık testi sonucunda ölçek geneline ilişkin Cronbach alfa değeri 0.89 bulunmuştur.

\section{Verilerin Analizi}

Veriler, SPSS 21 ile analiz edilmiştir. Analiz edilen veriler, çizelgeler oluşturularak açıklanmış ve yorumlanmıştır. Grupların birbirleriyle olan ilişkilerinin ya da ortalamalar arasındaki farkların anlamlılık testinde ise $\mathrm{p}<0.05$ düzeyi esas alınmıştır. Ebeveynlerin demografik özelliklerine göre Milner Çocuk İstismarı Potansiyel Envanterinden aldıkları puanların karşılaştırılmasında kullanılacak olan hipotez testlerinin belirlenmesi amacıyla bağımsız değişkenlere göre ölçek puanlarının normal dağılımı uyumu Kolmogorov-Smirnov testi ile incelenmiş ve veri setinin normal dağılma uymadığ kategoriden oluşması durumunda ölçek puanları Mann-Whitney U testi, ikiden fazla kategoriden oluşması durumunda ise Kruskal-Wallis testi ile karşılaştırılmıştır. Yapılan Kruskal-Wallis testi neticesinde istatistiksel olarak anlamlı bir fark çıkması durumunda farkın hangi kategorilerden kaynaklandığı Mann-Whitney U testi ile belirlenmiştir.

\section{Sonuçlar}

Araştırmaya katılan ebeveynlerin Milner Çocuk İstismarı Potansiyel Envanteri istismar puan ortalamaları $133.57 \pm 73.19$ 'dur. Ebeveynlerin aldıkları en düşük puan 13, en yüksek puan ise 337'dir.Ebeveynlerin Çocukluk Çağı Travmaları Ölçeği’nden aldıkları puanlara bakıldığında ise, ölçeğin geneline ilişkin puan ortalamalarının 34.65 10.45 olduğu, aldıkları en düşük puanın 22, en yüksek puan ise 6 olduğu görülmektedir. Ebeveynlerin Hacettepe Kişilik Envanterinden aldıkları toplam puan ortalamasının toplamı ise 103.27 18.99 olduğu saptanmıştır. Envanterden alınan en düşük puan 53, en yüksek puan 147'dir. Ebeveynlerin demografik özelliklerine göre çocuk istismarı potansiyellerinin karşılaştırılmasına ilişkin analiz sonuçları Tablo 1'de verilmiştir. 
Tablo 1. Ebeveynlerin Demografik Özelliklerine Göre Çocuk İstismarı Potansiyellerinin Karşılaştırılması

\begin{tabular}{|c|c|c|c|c|c|}
\hline Demografik Özellikler & $\mathbf{n}$ & Sira Ort. & $\mathbf{x}^{2} / \mathbf{Z}^{\mathrm{a}}$ & p & Fark \\
\hline \multicolumn{6}{|l|}{ Cinsiyet } \\
\hline Kadın & 143 & 99.31 & -2.74 & $0.01^{*}$ & \\
\hline Erkek & 71 & 123.99 & & & \\
\hline \multicolumn{6}{|l|}{ Yaş Grubu } \\
\hline 30 yaş ve altı & 43 & 106.28 & 0.03 & 0.99 & \\
\hline $31-40$ yaş arası & 110 & 107.56 & & & \\
\hline 41 yaş ve üzeri & 61 & 108.25 & & & \\
\hline \multicolumn{6}{|l|}{ Doğum yeri } \\
\hline Türkiye & 81 & 113.12 & 4.52 & 0.10 & \\
\hline Kibris & 107 & 99.16 & & & \\
\hline Diğer & 26 & 124.29 & & & \\
\hline \multicolumn{6}{|l|}{ Medeni Durumu } \\
\hline Evli & 189 & 106.19 & -0.85 & 0.39 & \\
\hline Bekar/Boşanmış/Dul & 25 & 117.44 & & & \\
\hline \multicolumn{6}{|l|}{ Öğrenim Durumu } \\
\hline İlköğretim ve alt1 & 21 & 119.33 & 13.73 & $0.01 *$ & $1-4$ \\
\hline Lise & 74 & 114.67 & & & $1-5$ \\
\hline Ön Lisans & 22 & 132.41 & & & $2-5$ \\
\hline Lisans & 71 & 101.11 & & & $3-4$ \\
\hline Lisansüstü & 26 & 73.90 & & & $3-5$ \\
\hline \multicolumn{6}{|l|}{ Çalışma durumu } \\
\hline Çalışan & 172 & 105.42 & $-1,00$ & 0.32 & \\
\hline Çalışmayan & 42 & 116.04 & & & \\
\hline \multicolumn{6}{|l|}{ Çocuk Sayısı } \\
\hline Tek çocuk & 117 & 114,45 & 3.62 & 0.16 & \\
\hline İki çocuk & 73 & 96.94 & & & \\
\hline Üç ve üzeri & 24 & 105.75 & & & \\
\hline \multicolumn{6}{|l|}{ Evin mülkiyeti } \\
\hline Kira & 66 & 123.72 & 11.62 & $0.01 *$ & $1-2$ \\
\hline Kendisine ait & 132 & 98.76 & & & $1-4$ \\
\hline Lojman & 7 & 149.29 & & & $2-3$ \\
\hline Diğer & 9 & 84.22 & & & $3-4$ \\
\hline \multicolumn{6}{|l|}{ Gelir düzeyi } \\
\hline İyi & 89 & 105.21 & 1.98 & 0.37 & \\
\hline Orta & 120 & 107.63 & & & \\
\hline Kötü & 5 & 145.20 & & & \\
\hline
\end{tabular}

$Z^{\mathbf{a}}$ değeri Mann-Whitney $U, x^{2}$ değeri ise Kruskal-Wallis testine ilişkin sonuçları belirtmektedir. ${ }^{*}<0.05$

Ebeveynlerin demografik özelliklerine göre çocuk istismarı potansiyellerinin karşılaştırılmasına ilişkin Tablo 1 incelendiğinde, CIPE sıra ortalamalarının ebeveynlerin cinsiyetlerine göre farklılaştı̆̆ $(Z=-2.74, p<.05)$, sıra ortalamaları dikkate alındığında erkeklerin çocuk istismarı potansiyellerinin (123.99), kadınlarınkinden (99.31) daha yüksek oluğu görülmüştür. Ebeveynlerin çocuk istismarı potansiyellerinin, öğrenim durumlarına göre de istatiksel açıdan anlamlı bir şekilde farklılaştığ $1\left(\mathrm{x}^{\mathrm{x}}=13.73, \mathrm{p}<.05\right)$; ilk öğrenim ve altı (119.33), lise (114.67) ve ön lisans (132.41) düzeyinde öğrenimi olan ebeveynlerin çocuk istismarı potansiyellerinin lisans $(101,11)$ 
ve lisans üstü $(73,90)$ öğrenimi düzeyine sahip ebeveynlerden yüksek olduğu görülmüştür. Tablo 1'de yer alan istatiksel açıdan anlamlı bir diğer sonuçta evin mülkiyeti değişkenine ilişkindir $\left(\mathrm{x}^{\mathrm{x}}=11.62, \mathrm{p}<.05\right)$. Kirada (123.72) ve lojmanda (149.29) oturduğunu belirten ebeveynlerin istismar potansiyellerinin diğer ebeveynlerden daha yüksek olduğu tespit edilmiştir. Tablo 2 incelendiğinde ebeveynlerin çocuk istismarı potansiyellerinin yaş grubu $\left(\mathrm{x}^{\mathrm{x}}=0,03, \mathrm{p}>.05\right)$, doğum yeri $\left(\mathrm{x}^{\mathrm{x}}=4,52, \mathrm{p}>.05\right)$, medeni durumu $(\mathrm{Z}=--0,85, \mathrm{p}>.05)$, çalışma durumu $(\mathrm{Z}=-1,00$, $\mathrm{p}>.05)$, çocuk sayısı $\left(\mathrm{x}^{\mathrm{x}}=3,62, \mathrm{p}>.05\right)$ ve gelir düzeyi $(Z=1,98, \mathrm{p}>.05)$ değişkenlerine göre farklılaşmadığ 1 tespit edilmiştir.

Araştırma kapsamında değerlendirilen cinsiyet, öğrenim durumu ve oturulan evin mülkiyeti değişkenleri ile ebeveynlerin Çocukluk Çağı Travmaları Ölçeği ve Hacettepe Kişilik Envanterinden aldıkları puanların istismar potansiyellerini yordayıp yordamadıkları ve yordama düzeyleri hiyerarşik regresyon modeli ile incelenmiştir. Regresyon analizine geçmeden önce regresyon analizinin varsayımları incelenmiştir. Öncelikle bağımlı ve bağımsız değişkenlerin çok değişkenli normal dağılıma uyumu incelenmiştir. Standardize atık değerler ve saçılma diyagramı dikkate alındığında veri setinin çok değişkenli normal dağılma uyduğu tespit edilmiştir. Hata terimleri arasında otokorelasyon olup olmadığına ilişkin analiz Durbin-Watson (D-W) değeri ile incelenmiştir. Yapılan analiz neticesinde D-W değerinin 1.809 olduğu belirlenmiş ve otokorelasyon olmadığı belirlenmiştir. Çoklu doğrusal bağlantının saptanması amacıyla ise VIF ve tolerans değerleri incelenmiştir. VIF değerinin 10'dan küçük olması ve tolerans değerinin 0.10 'dan büyük olması çoklu doğrusal bağlantının olmadığını göstermektedir. Çoklu doğrusal bağlantıya ilişkin sonuçlar incelediğinde, tahmincilere ait tolerans değerlerin 0.36 ile 0.98 arasında değiştiği yani 0.10 'dan büyük olduğu tespit edilmiştir. Ayrıca VIF değerlerinin 1.01 ile 1.50 arasında değiştiği yani 10 'dan küçük olduğu saptanmıştır. Ayrıca değişkenlerin eş varyanslı oldukları görülmektedir. Bu sonuçlara göre, regresyon analizinin tüm varsayımları karşılanmıştır. Regresyon analizi sonuçları Tablo 2'de verilmiştir.

Çocuk istismarı potansiyelinin yordanmasına ilişkin hiyerarşik regresyon sonuçları Tablo 2'de verilmiştir. Analizin ilk aşamasında cinsiyet, öğrenim durumu ve evin mülkiyeti değişkenleri modele dahil edilmiştir. Analiz sonucunda bu değişkenlerin birlikte çocuk istismarı potansiyeli ile istatistiksel açıdan anlamlı bir ilişki verdiği tespit edilmiştir $\left(\mathrm{R}=0.234, \mathrm{R}^{2}=\right.$ $0.055, \mathrm{p}<.05)$. $\mathrm{Bu}$ aşamadaki değişkenler birlikte, varyansın sadece $\% 0.5$ 'ini açıklamaktadır. Regresyon analizi baz alınarak hazırlana t-testi sonuçlarına göre, birinci modelde yalnızca cinsiyet değişkeninin çocuk istismarı potansiyelinin anlamlı birer yordayıcısı olduğu sonucuna ulaşılmıştır.

Analizin ikinci aşamasında ise Çocukluk Çağı Travmaları Ölçeği modele dahil edilmiştir. Cinsiyet, öğrenim durumu, evin mülkiyeti ve Çocukluk Çağı Travmaları Ölçeği'ni oluşturan Fiziksel İstismar, Duygusal İstismar, Cinsel İstismar, Duygusal İhmal, Fiziksel İhmal alt boyutlarıyla birlikte, çocuk istismarı potansiyeli ile anlamlı bir ilişki verdiği görülmektedir $(\mathrm{R}=$ $0.524, \mathrm{R}^{2}=0.274 \mathrm{p}<.001$ ). Çocuk İstismarı Potansiyeli Envanteri ve Çocukluk Çağı Travmaları Ölçeği'nin alt boyutlarından alınan puanlar arasındaki ikili korelasyonlara bakıldığında korelasyon katsayılarının .359 ve .413 arasında değiştiği ve bu değerlerin pozitif yönde ve orta güçte korelasyona işaret ettiği görülmektedir. Bu aşamadaki değişkenler birlikte, varyansın \%27'sini açıklamaktadır. Regresyon analizine ilişkin t-testi sonuçlarına göre, ikinci modelde sadece cinsel istismar değişkeninin çocuk istismarı potansiyelinin anlamlı birer yordayıcısı olduğu görülmektedir. 
Tablo 2. Çocuk İstismarı Potansiyelinin Yordanmasına İlişkin Hiyerarşik Regresyon Analizi Sonuçları

\begin{tabular}{|l|c|c|c|c|c|c|}
\hline Değişkenler & $\boldsymbol{B}$ & $\boldsymbol{S t}$. & $\boldsymbol{\beta}$ & $\boldsymbol{t}$ & $\boldsymbol{p}$ & Ikili $\boldsymbol{r}$ \\
\hline $\begin{array}{l}\text { Aşama 1 } \\
\text { Sabit }\end{array}$ & 157.013 & 28.459 & - & 5.517 & $<.001$ & - \\
\hline Cinsiyet & 23.364 & 10.505 & .151 & 2.224 & .027 & .168 \\
\hline Öğrenim durumu & -6.993 & 3.989 & -.119 & -1.753 & .081 & -.151 \\
\hline Evin Mülkiyeti & -10.710 & 7.166 & -.101 & -1.495 & .137 & -.114 \\
\hline$F_{3,210}=4.059, p<.05, R=0.234, R^{2}=0.055$ & & & & & & \\
\hline Aşama 2 & & & & & & \\
\hline Sabit & 66.665 & 27.961 & - & 2.38 & .018 & - \\
\hline Duygusal istismar & 5.07 & 2.836 & .175 & 1.79 & .075 & .383 \\
\hline Fiziksel istismar & .257 & 2.645 & .010 & .097 & .923 & .359 \\
\hline Fiziksel ihmal & 2.51 & 2.135 & .116 & 1.17 & .241 & .413 \\
\hline Duygusal ihmal & 1.76 & 1.053 & .150 & 1.68 & .095 & .378 \\
\hline Cinsel istismar & 5.73 & 2.806 & .170 & 2.04 & .042 & .386 \\
\hline$F_{8,205}=9.691, p<.001, R=0.524, R^{2}=0.274$ & & & & & & \\
\hline Aşama 3 & & & & & & \\
\hline Sabit & & & & & \\
\hline Kişisel uyum & 337.948 & 33.928 & - & 9.3 & $<.001$ & - \\
\hline Sosyal uyum & -2.916 & 0.368 & -.422 & -7.929 & $<.001$ & -.578 \\
\hline$F_{10,203}=30.021, p<.001, R=0.772, R^{2}=0.597$ & -2.029 & 0.456 & -.284 & -4.451 & $<.001$ & -.636 \\
\hline Beta değerleri & & & & & & \\
\hline
\end{tabular}

*Beta değerleri her bir aşamada modele dahil edilen değişkenlere iliş̧kindir.

Analizin üçüncü aşamasında ise Hacettepe Kişilik Envanteri'nin Kişisel Uyum ve Sosyal Uyum alt boyutları modele dahil edilmiştir. Elde edilen sonuca göre cinsiyet, öğrenim durumu, evin mülkiyeti, Çocukluk Çağı Travmaları Ölçeği ve Hacettepe Kişilik Envanteri'nin birlikte çocuk istismarı potansiyeli ile anlamlı bir ilişki verdiği görülmektedir $\left(\mathrm{R}=0.772, \mathrm{R}^{2}=0.597, \mathrm{p}<.001\right)$. Çocuk İstismarı Potansiyeli Envanteri ve Hacettepe Kişilik Envanteri'nin alt boyutlarından alınan puanlar arasındaki ikili korelasyonlar incelendiğinde, korelasyon katsayılarının Kişisel Uyum alt boyutu için -.587, Sosyal Uyum alt boyutu için -.636 olduğu ve bu değerlerin negatif yönde ve orta güçte korelasyona işaret ettiği görülmektedir. Bu aşamadaki değişkenler beraber, varyansın \%59'unu açıklamaktadır. Standardize edilmiş regresyon katsayısına göre $(\beta)$ yordayıcı değişkenlerin çocuk istismarı potansiyeli üzerindeki göreceli önem sırası kişisel uyum ve sosyal uyum şeklindedir. Regresyon analizine ilişkin t-testi sonuçlarına göre, üçüncü modelde her iki alt boyutun da çocuk istismarı potansiyelinin anlamlı birer yordayıcısı olduğu görülmektedir.

\section{Tartışma}

Ebeveynlerin çocuk istismarı potansiyellerini yordayan faktörlerin incelenmesi amacıyla yapılan bu çalışmada elde edilen sonuçlara göre, ebeveynlerin çocuk istismarı potansiyellerinin cinsiyet, öğrenim durumu ve oturdukları evin mülkiyetine göre farklılaştı̆̆ tespit edilmiştir. Bu sonuca göre, babaların çocuk istismarı potansiyellerinin annelerden daha fazla olduğu görülmektedir. Yapılan pek çok çalışmada (Oral 2001; Schaeffer et al. 2005) babaların çocuklarını istismar etme düzeylerinin, annelere göre daha yüksek olduğu ortaya konmuştur.

Türkiye'de geleneklerin ve ataerkil yapının, cinsiyet rolleri üzerinde etkili olduğu ve erkeklik olgusunun, sertlik, saldırganlık gibi özelliklerle ilişkilendirildiğine dikkat çekilmektedir (Zeybekoğlu 2013). Bu geleneksel yapı içinde çocukların, eğitim gerekçesiyle şiddet içeren tutum ve davranışlara daha sık maruz kaldıkları ifade edilmektedir (Göker et al. 2010; Şahin 
2014). Erkeklik olgusunun güç ve iktidar sahibi olma ile özdeşleştirilmesinin erkeklerin evlerine yabancılaşmalarına ve evin maddi sorumluluğunu yerine getirme kaygısı ile yoğun stres yaşamalarına neden olduğu belirtilmektedir (Lee et al. 2012). Erkeklerin yaşadıkları psikolojik ve ekonomik stres düzeyinin babalık rollerine de yansıyor olabileceği ve çocuklarına yönelik şiddet davranışını artırabileceği düşünülmektedir.

Araştırmada elde edilen bir diğer sonuca göre ise, çocuk istismarı potansiyeli ebeveynlerin öğrenim düzeyine göre farklılaşmaktadır. Elde edilen bu sonuca göre ebeveynlerin öğrenim düzeyinin azaldıkça çocuk istismarı potansiyellerinin artabileceği düşünülmektedir. Öğrenim düzeyinin, çocuğa yönelik istismar ile ilişkisini ortaya koyan çeşitli çalı̧̧malara göre de öğrenim düzeyi yükseldikçe ebeveynlerin çocuklarını istismar etme düzeyleri azalmaktadır (Işıkhan ve Yıldırım 2006; Aktaş 2011). Literatürde, eğitim seviyesi düşük olan ebeveynlerin, çocuklarının daha sık istismara maruz kaldıkları ileri sürülmüştür. Anne babanın eğitim düzeyinin hem istismara uğrama riskini hem de istismar sonrası ruhsal etkilenme düzeyini belirlediği ifade edilmiştir (Şimsek \& Gençoğlan 2014).İstismara maruz kalan çocuklarda kısa ve uzun dönem ruhsal etkilenmelerin olabileceği ifade edilmektedir. Çalışmalarda \%10 ile \%64 arasında değişen oranlarda en sık konulan tanın ise travma sonrası stres bozukluğu olduğu belirtilmektedir (Şimsek 2011). Araştırmada çocuk istismarı potansiyelinin, oturulan evin mülkiyetine göre farklılaştığı kirada ve lojmanda oturan ebeveynlerin istismar potansiyellerinin diğer ebeveynlerden daha yüksek olduğu tespit edilmiştir. Kutsal (2004) tarafindan yapılan çalışmada da çocuklarına istismar uyguladığı tespit edilen ebeveynlerin \%56.3'ünün gecekonduda yaşadığı ve \%57.7'sinin ev sahibi olmadığı tespit edilmiştir. Çalışmamızda evin mülkiyet durumu sosyoekonomik değişkenlerden biri olarak ele alınmıştır. Konut koşullarının, işsizlik, düşük gelir düzeyi ve düşük öğrenim düzeyi gibi ekonomik ve sosyal stresörlerden biri olduğuna dikkat çekilmektedir (Polat 2007). Bu bağlamda, sosyo-ekonomik düzeyin düşük olmasının aile kaynaklarını azalttığı, bu durumunda ebeveyn üzerindeki stresi arttırarak çocuğa yönelik istismar potansiyelinin artmasına neden olabileceği düşünülmektedir.

Araştırmada çocuk istismarı potansiyelini yordayan faktörlere ilişkin olarak yapılan hiyerarşik regresyon analizinde cinsiyet, öğrenim düzeyi ve oturulan evin mülkiyeti değişkenlerinin ebeveynlerin çocuk istismarı potansiyellerini yordayıp yordamadıkları incelenmiş; bu değişkenlerin çocuk istismarı potansiyeli ile istatistiksel açıdan anlamlı bir ilişki verdiği ancak t-testi sonuçlarına göre, birinci aşamada yalnızca cinsiyet değişkeninin çocuk istismarı potansiyelinin anlamlı birer yordayıcısı olduğu görülmüştür. İkinci aşamada ise, ebeveynlerin çocuk istismarı potansiyellerinin Çocukluk Çağı Travmaları Ölçeği'ni oluşturan Fiziksel İstismar, Duygusal İstismar, Cinsel İstismar, Duygusal İhmal, Fiziksel İhmal alt boyutları ile anlamlı ve pozitif yönde bir ilişki verdiği görülmüş; cinsiyet, öğrenim durumu ve oturulan evin mülkiyeti değişkenleri ile birlikte çocukluk çağı istismar yaşantılarının ebeveynlerin çocuklarına yönelik istismar potansiyelini yordayan faktörlerden biri olduğu görülmüştür. Bu sonucun, çocukluğunda istismara ve ihmale maruz kalan ebeveynlerin çocuk istismarı potansiyellerinin daha yüksek olduğu şeklinde yorumlanabileceği düşünülmektedir. Ertem, Leventhal ve Dobbs (2000) tarafından yapılan bir çalışmada çocukluğunda istismara maruz kalan ebeveynlerin yaklaşık \%30'unun kendi çocuklarını istismar etmeye devam ettiklerini ve bu çocukların ölüm oranlarının \%7 ile \%70 arasında değiştiğini ifade etmektedirler. Çocukluk dönemindeki istismar yaşantısının kuşaklar arası bir istismar döngüsü oluşturduğu ve çocukluğunda cinsel istismara maruz kalan ebeveynlerin kendi çocuklarını istismar edebildikleri belirtilmektedir (Bilge 2005; Özbay 2010; Pears \& Capaldi 2001). Çocukluğunda istismar yaşantısı olan ebeveynlerin, kendi anne babalarıyla güvensiz bir bağlanma ilişkisi kurdukları, bu nedenle aşırı kaygılı ve strese yatkın hale gelebildikleri ve ebeveynleriyle olan ilişkilerinde yaşadıkları hayal kırıklıklarını 
kendi çocuklarına yansıtabildikleri düşünülmektedir.

Araştırmadan elde edilen bir diğer sonuca göre cinsiyet, öğrenim durumu, evin mülkiyeti, Çocukluk Çağı Travmaları Ölçeği ve Hacettepe Kişilik Envanteri'nin birlikte çocuk istismarı potansiyeli ile anlamlı bir ilişki verdiği görülmüştür. Ebeveynlerin çocuk istismarı potansiyelleri ile Hacettepe Kişilik Envanteri'nin Kişisel Uyum ve Sosyal Uyum alt boyutları arasındaki korelasyonlar incelendiğinde, istatistiksel açıdan anlamlı ve negatif yönde bir ilişki tespit edilmiştir. $\mathrm{Bu}$ sonuca göre, ebeveynlerin çocuk istismarı potansiyelleri arttıkça kişisel ve sosyal uyum düzeyleri azalmaktadır.

Çocukluk döneminde istismara maruz kalmanın, bireyin kendilik algısı üzerinde olumsuz etkilerinin olduğu, bu nedenle erişkinlik döneminde bu kişilerin olumlu ilişkiler kuramadıkları (Yılmaz, 2009); çeşitli psikolojik ve sosyal uyum güçlükleri yaşadıkları genellikle başa çıkma mekanizmalarından yoksun oldukları ve problem çözme becerilerinin yetersiz olduğu belirtilmektedir (Karakoç 2009; Özdemir 2009; Çabuk 2015).Özellikle çocuklarını fiziksel olarak istismar etme eğiliminde olan ebeveynlerin sosyal uyum güçlükleri yaşadıkları, dürtü kontrollerinin zayıf olduğu ve anti-sosyal davranışlar sergilemeye yatkın oldukları ifade edilmektedir (Dünya Sağlık Örgütü 2002; Yalçınkaya 2011).

Elde edilen sonuçlar genel olarak incelendiğinde, sosyo-demografik değişkenlerin, çocukluk çağı istismar yaşantılarının ve çeşitli kişilik özelliklerinin ebeveynlerin çocuklarına yönelik istismar potansiyelini artırabilecek faktör olabileceği görülmektedir. Ebeveynlerin çocuklarına yönelik istismar potansiyellerini etkileyen unsurların belirlenmesi toplumsal açıdan önleyici çalışmaların yapılması açısından önem taşımaktadır. Türkçe alan yazında çocuk istismarı ile ilgili çok sayıda araştırma bulunmakla birlikte, konuyu ebeveynlerin çocuk istismarına yönelik potansiyelleri bağlamında ele alan çalışmalar bulunmamaktadır. Bu araştırma, Kuzey Kıbrıs örnekleminde ebeveynlerin çocuk istismarı potansiyelini etkileyebilecek unsurları ele alan ilk çalışma olması açısından önem taşımaktadır. Bununla birlikte, çalışmanın çeşitli sınırlılıkları da mevcuttur. Araştırmada yer alan ebeveynlere öz bildirime dayalı veri toplama araçları uygulanmıştır. Yanlış hatırlama ya da sosyal açıdan kabul edilebilir yanıtlar verme eğiliminin ebeveynlerin verdikleri yanıtları etkileyebileceği düşünülmektedir. Kuzey Kıbrıs son yıllarda ada dışından önemli ölçüde göç almaktadır. Göç olgusunun çeşitli sosyo-ekonomik stresörlerle ilişkisi düşünüldüğünde, konu ile ilgili gelecekte yapılacak çalışmalarda, Kuzey Kıbrıs'ın kendine özgü toplumsal koşullarının da dikkate alınması önem taşımaktadır. Çocuk istismarı potansiyelinin stres, mutsuzluk, katılık gibi psikolojik özelliklerle ilişkili olduğu düşünüldüğünde, anne babalara çocukluk çağlarında yaşadıkları sorunların kendi çocuklarıyla olan ilişkilerine olumsuz yansımaları konusunda farkındalık kazandırılması ve çocukluk dönemi yaşantıları nedeniyle yaşadıkları sorunların çözümü için uzman yardımı almaları konusunda gerekli desteğin sağlanmasının önleyici çalışmalar açısından önem taşıdığı düşünülmektedir. 


\section{KAYNAKÇA}

Aktaş E. (2011). Çocuklardaki Dikkat Eksikliği Hiperaktivite Bozukluğu ve Özgül Öğrenme Güçlügünün, Anne Babaların Duygusal İstismar Farkindalığ, İstismar Potansiyeli ve Çocukların Kabul/Red Alglsl ile İlişkisi. Tipta Uzmanlık Tezi. Ankara Üniversitesi. Ankara.

Aktepe E. (2009). "Çocukluk Çağı Cinsel İstismarı". Psikiyatride Güncel Yaklaşımlar 1 (2009) 95-119.

Allen B. \& Lauterbach D. (2007). "Personality Characteristics of Adult Survivors of Childhood Trauma". J Trauma Stress 20/4 (2007) 587-95.

Altıparmak S., Yıldırım G., Yardımcı F. \& Ergin, D. (2013). "Annelerden Alınan Bilgilerle Çocuk İstismarı ve Etkileyen Etkenler". Anatolian Journal of Psychiatry 14 (2013) 354-361. Doi: 10.5455/apd.39819.

Ayaz T., Yılmaz-Özpolat A., Yücel D., Altunöz U. (2013). "Kendi Çocuğunu Fiziksel Olarak İstismar Eden ve Kendisi de Fiziksel İstismar Gören Bir OKB Vakası". Bilişsel Davranışçı Psikoterapi ve Araşttrmalar Dergisi 2 (2013) 116-120.

Aydemir Ö. \& Köroğlu E. (2006). "Psikiyatride Kullanılan Klinik Ölçekler". Hekimler Yayın Birliği (2006) 46-87.

Azizoğlu M. (2009). Lise Ergenlerinde Duygusal İstismarın Başarlya Etkisi. Yüksek Lisans Tezi. Yeditepe Üniversitesi, Sosyal Bilimler Enstitüsü, Eğitim Yönetimi ve Denetimi Programı, İstanbul 2009.

Beyazova U. (2014). Çocuk İstismarına ve İhmaline Yaklaşım. Temel Bilgiler. Ankara 2014.

Bilge D. Y., Taşar A. M., Kılınçoğlu B., Özmen S. \& Tıraş Ü. (2013). "Alt Sosyoekonomik Düzeye Sahip Anne-Babaların Çocuk İstismarı ve İhmali Hakkındaki Bilgi Düzeyleri, Deneyimleri ve Kullandıkları Disiplin Yöntemleri”. Anadolu Psikiyatri Dergisi 14 (2013) 27-35.

Bilge R. (2009). "Aile İçinde Şiddet veya Şiddete Uğrayan Çocukların Okul Yaşantılarında Ortaya Çıkan Sorunlar ve Çözüm Önerileri”. Çocuk ve Şiddet Çalıştayı (2009) 50-63.

Bower-Russa M. E., Knutson J. F. \& Winebarger A. (2001). "Disciplinary History, Adult Disciplinary Attitudes, and Risk for Abusive Parenting”. Journal of Cominity Psychology 29/3 (2001) 219-240. Doi: $10.1002 /$ jcop. 1015.

Can. M., Tırıtıl L. \& Dokgöz H. (2009). “Çocuk İstismarı Olgularında Hekim”. Klinik Gelişim (2009) 8994.

Çabuk C. O. (2015). The Roles of Childhood Trauma, Personality Characteristics, and Interpersonal Problems on Psychological Well-Being. Yayımlanmış Yüksek Lisans Tezi. Orta Doğu Teknik Üniversitesi. Ankara.

Çakıc M., Çakıcı E., Tatlısu Ö., Bekiroğulları Z. \& Aksoy A. (2003). Kuzey Kıbrıs'ta Çocuk İstismarı Yayginliğl. Lefkoşa 2003.

Çengel-Kültür E., Çuhadaroğlu-Çetin F. \& Gökler B. (2007). "Demographic and Clinical Features of Child Abuse and Neglect Cases". The Turkish Journal of Pediatrics 49 (2007) 256-262.

Dallar-Bilge Y., Taşar M. A., Kılınçoğlu B., Özmen S. \& Tıraş Ü. (2013). “Alt Sosyoekonomik Düzeye Sahip Anne-Babaların Çocuk İstismarı ve İhmali Hakkındaki Bilgi Düzeyleri, Deneyimleri ve Kullandıkları Disiplin Yöntemleri”. Anadolu Psikiyatri Dergisi 14 (2013) 27-35.

Demir M. (2008). Çocuk ve Ergenlerin Cinsel İstismart Sonrasinda Akut Stres Bozukluğu ve Travma Sonrası Stres Bozukluğu Özelliklerinin İncelenmesi. Yayınlanmamış Uzmanlık tezi. Uludağ Üniversitesi, Bursa 2008.

Douglas E. M. (2014). "A Comparison of Child Fatalities by Physical Abuse Versus Neglect: Child, Family, Service, and Worker Characteristics". Journal Of Social Service Research 40 (2014) 259-273.

Dünya Sağlık Örgütü (2002). World Report on Violence and Health. Geneva 2002.

Dünya Sağlık Örgütü (2014). "Child Maltreatment (“child abuse")". Kaynak: <http://search.who.int/search ?q=child+abuse\&ie=utf\&\&site=who\&client=_en_r\&proxystylesheet=_en_r\&output=xml_no_$\mathrm{dtd} \&$ oe $=$ utf $\&$ getfields $=$ doctype $>$.

Ertem I., Leventhal J. \& Dobbs S. (2000). "Intergenerational Continuity of Child Physical Abuse: How Good is The Evidence?". Lancet 356 (2000) 814-819.

Göker Z., Aktepe E., Hesapçığlu S. T. \& Kandil S. T. (2010). "Cinsel İstismar Suçlusu Olarak Çocuk ve 
Ergenler: Olgu Serisi”. Klinik Psikiyatri 12 (2010) 141-146.

Gravetter J. F. \& Forzano L. B. (2012). Research Methods for the Behavioral Sciences. USA $2012^{4}$.

Işıkhan V. \& Yıldırım Ş. S. (2006). "Ergenlerin Aile İçi Şiddete Maruz Kalma Durumları Ve Aile İlişkilerinin Değerlendirilmesi”. Toplum ve Sosyal Hizmet Dergisi 17/2 (2006) 73-90.

İşmen A. E. (2004). “Aile İçi Çocuk İstismarı Ölçek Geliştirme Çalışması”. Hasan Ali Yücel Eğitim Fakültesi Dergisi 1 (2004) 207-221.

Kara B., Biçer Ü. \& Gökalp A. S. (2004). “Çocuk İstismarı”. Çocuk Sağlığı Hastalıkları Dergisi 47 (2004) $140-51$.

Karakoç S. (2009). “Aile Içi Şiddetin Çocuk Ruh Sağlı̆̆ına Etkileri”. Çocuk ve Şiddet Çalıştayı (2009)19-23.

Kezer İ. (2014). Çocuk İhmal ve İstismarında Risk Etmenleri. Çocuk İstismarına ve İhmaline Yaklaşım. Temel Bilgiler. Ankara 2014.

Köse D., Çınar N. \& Altınkaynak S. (2013). "Yeni Doğanın Anne ve Baba ile Bağlanma Süreci”. Sürekli Tip Ĕ̈itimi Dergisi 22/6 (2013) 232-245.

Kutsal E. (2004). Fiziksel Çocuk İstismarının Sosyo demografik Özellikleri ve Milner Çocuk İstismarı Potansiyeli Ölçeğinin Türkiye Geçerliliği. Yayımlanmamış Uzmanlık Tezi. Gazi Üniversitesi Tıp Fakültesi. Ankara 2004.

Küpeli S., Kanbur N. \& Derman O. (2003). “Çocuk İstismarı: Bir Olgu Sunumu”. STED 12/4 (2003) 129130.

Lee M. A., Schoppe-Sullivan S. J. \& Dush C. M. K. (2012). "Parenting Perfectionism and Parental Adjustment". Personality and Individual Differences 52 (2012) 454-457.

Milner J. S. (1986). Potential Inventory (CAP) Web. Kaynak: <http://www3.parinc.+/products/ product. aspx? $>$. Productid $=$ CAP.National Data Archive on Child Abuse and Neglect (NCANDS). (2015), Department of Health and Human Services, Administration for Children and Families, Administrationon Children, Youth and Families. <https://www.escap.eu/bestanden/Research/San $\% 20$ Diego\%202017/childrensbureau2015report.pdf $>$.

Milner J. S., Charlesworth J. R., Gold R. G., Gold S. R. \& Friesen M. R. (1988). "Convergent validity of the Child Abuse Potential Inventory”. Journal of Clinical Psychology 44/2 (1988) 281-285.

Oral R., Can D. \& Kaplan S. (2001). "Child Abuse in Turkey: An Experience in Overcoming Denial and a Description of 50 Cases". Child Abuse and Neglect 25 (2001) 279-90.

Özbay N. (2010). Çocuğa Yönelik Cinsel Saldırıda Bulunanların Sosyo-Demografik ve Kişilik Özellikleri. Yüksek Lisans Tezi. Maltepe Üniversitesi, Sosyal Bilimler Enstitüsü, Psikoloji Anabilim Dalı, İstanbul 2010.

Özdemir N. (2009). “Aile İçi Şiddette Uğrayan ya da Tanık Olan Çocuğa Danışmanlık ve Aile Içi Şiddete Yaklaşım”. Çocuk ve Şiddet Çalıştayı (2009) 64-72.

Özgüven E. (1992). Hacettepe Kişilik Envanteri (HKE), Psikolojik Danışma Rehberlik ve Eğitim Merkezi (PDREM). Ankara 1992.

Öztep İ. C. (2010). Duygusal İstismar Algllayan ve Algllamayan Öğrencilerin Kaygı Düzeyleri ve Denetim Odaklarının Karşılaştırılması. Yüksek Lisans Tezi. Maltepe Üniversitesi, Sosyal Bilimler Enstitüsü, Adli Klinik Psikoloji Programı, İstanbul 2010.

Pears K. C. \& Capaldi D. M. (2001). "Intergenerational Transmission of Abuse: a Two-Generational Prospective Study of an at-Risk Sample”. Child Abuse \& Neglect 25 (2001) 1439-1461.

Pekdoğan S. (2016). “Annelerin İstismar Potansiyellerinin Bazı Değişkenler Açısından İncelenmesi”. Ege Ĕgitim Dergisi 17/2 (2016) 425-441.

Polat O. (2007). Tüm Boyutlarıyla Çocuk İstismarı 1 Tanımlar. Ankara 2007.

Schaeffer C., Alexander P., Bethke K. \& Kretz L. (2005). "Predictors of Child Abuse Potential Among Military Parents: Comparing Mothers and Fathers”. Journal of Family Violence 20 (2005) 123-129.

Sebre S., Sprugevica I., Novotni A., Bonevski D., Pakalniskiene V., Popescu D., Turchina T., Friedrich W. \& Lewis O. (2004). "Cross-Cultural Comparisons of Child-Reported Emotional and Physical Abuse: Rates, Risk Factors and Psychosocial Symptoms”. Child Abuse \& Neglect 28 (2004) 113-127.

Siyez D. M. (2003). Duygusal Istismara Maruz Kalan ve Kalmayan Ergenlerin Benlik Algllarl ile Dep- 
resyon ve Kaygı Düzeylerinin Karşılaştırılması. Yüksek Lisans Tezi. Dokuz Eylül Üniversitesi, Eğitim Bilimleri Enstitüsü, Rehberlik ve Psikolojik Danışmanlık Anabilim Dalı, İzmir 2003.

Sosyal Hizmetler ve Çocuk Esirgeme Kurumu (2010). Türkiye'de Çocuk İstismarl ve Aile İçi Şiddet Araştırması, Özet Rapor.

Soylu N., Alplaslan A. H., Ayaz M., Esenyel S. \& Oruç M. (2013). "Psychiatric Disorders and Characteristics of Abuse in Sexually Abused Children and Adolescents With and Without Intellectual Disabilities". Research in Developmental Disabilities 34 (2013) 4334-4342.

Stewart C., Mezzich A. C. \& Bang-Shiuh D. (2006). "Parental Psychopathology and Paternal Child Neglect in Late Childhood". Journal of Child and Family Studies 15/5 (2006) 543-554.

Şahin F. (2009). "Çocuğun Fiziksel, Cinsel ve Duygusal İstismarı". Çocuk ve Şiddet Çalıştayı (2009) 24-26.

Şahin F. (2014). Fiziksel İstismar. Çocuk İstismarına ve İhmaline Yaklaşım. Temel Bilgiler. Ankara 2014.

Şar V., Öztürk E. \& İkikardeş E. (2012). "Çocukluk Çağı Ruhsal Travma Ölçeğinin Türkçe Uyarlamasının Geçerlilik ve Güvenilirliği’. Türkiye Klinikleri J Med Sci 32/4 (2012) 1054-1063.

Şimşek Ş. \& Gençoğlan S. (2014). "Cinsel İstismar Mağdurlarında İstismar Süresi ve Sıklığı ile Travma Belirtileri Arasındaki İlişskinin İncelenmesi”. Dicle Tip Dergisi 41/1 (2014) 166-171.

Şimşek Ş. (2011). "Post-Traumatic Stress Disorder in Children Who Were Sexually Abused and in Their Parents". Dicle Med J 38 (2011) 318-324.

Tackett K. K., Ericsson S. N., Cromer K. \& Hernandez A. (2009). "Health and Pain-Related Problems: The Role of Psychiatric Disorders and Current Life Stress". Journal of Trauma \& Dissociation a Review of Childhood Abuse 2/10 (2009) 1-37.

Tuna S. (2010). Aile İçi Çocuk Ístismarı: Annelerin Bazı Risk Faktörleri Açısından İncelenmesi. Yüksek Lisans Tezi. İstanbul Üniversitesi, Sosyal Bilimler Enstitüsü, Eğitim Bilimleri Anabilim Dalı, İstanbul 2010.

Tüzer V. \& Akdağ H. A. (2010). "Çocuğunun Derisini Yolan Anne: Bir Olgu Sunumu”. Nöropsikiyatri Arşivi 47 (2010) 263-266.

Tyler S., Allison K. \& Winsler A. (2006). "Child Neglect: Developmental Consequences, Intervention and Policy Implications". Child \& Youth Care Forum 35/1 (2006) 1-20.

United Nations International Children's Emergency Fund (UNICEF). (2014). The State of the World's Children 2014 in Numbers. New York 2014.

Yalçınkaya A. (2011). Kartal İlçesinde Çocukta Cinsel İstismar Olgularının Değerlendirilmesi. Yayımlanmamış Yüksek Lisans Tezi. Marmara Üniversitesi, İstanbul 2011.

Yavuzer H. (2003). Çocuğu Tanımak ve Anlamak. İstanbul 2003.

Yılmaz A. (2009). "Çocuk İstismarı ve İhmali: Risk Faktörleri ve Çocukların Psikososyal Gelişimi Üzerindeki Etkileri”. Civil Academy Sosyal Bilimler Dergisi 7/1 (2009) 63-79.

Zeybekoğlu Ö. (2013). "Günümüzde Erkeklerin Gözünden Babalık ve Aile”. MJH III/2 (2013) 297-328. 
